\title{
METHODOLOGICAL INSTRUMENTS FOR CHOOSING A STRATEGY FOR THE SUSTAINABLE DEVELOPMENT OF THE REGION
}

\author{
Bryukhovetskaya Natalya Ye., \\ Institute of the Economy of Industry of the NAS, Ukraine \\ E-mail: Bryukhovetskaya@nas.gov.ua \\ Korytko Tetyana $\mathrm{Yu}$ \\ Institute of the Economy of Industry of the NAS, Ukraine \\ E-mail: taniakorytko@gmail.com
}

Submission: 10/31/2019

Revision: 11/9/2019

Accept: 11/22/2019

\section{ABSTRACT}

The main objectives of this work are the development of methodological instruments for choosing a strategy to ensure the sustainable development of the region. This is a study of methods of survey and in-depth interviews. Methodological instruments have been developed to select the region's sustainable development strategy in the context of decentralization. The level of financial stability is determined by the integral indicator using multiple regression modeling. The risk of reducing the sustainable development of the region is calculated by identifying credit, political, general economic, sociodemographic, natural-environmental and investment risks by determining the values of losses and the likelihood of risk, followed by making a risk map. It has been suggested selecting the strategy for ensuring the sustainable development of the region on the basis of a matrix that includes the values of the integral indicator of financial stability and the index of risk of losing the sustainable development of the region. With the use of theses methodological instruments, a strategy was chosen to ensure the sustainable development of the region in emergency conditions using the example of a part of the Donetsk region.

Keywords: strategy, region, financial sustainability, risk, risk map 
DOI: 10.14807/ijmp.v11i6.1156

\section{INTRODUCTION}

Successful development of a region depends on the prospects and on the given opportunities, and on the ways they are used to give high standards of living to people. Ensuring of the sustainable development of the region is a topical issue of the current social and economic development of the country.

The most recent development of the region's economy to the region occurs under the unsatisfactory challenges of the environment. In this situation the development and effective instruments the state regulation policy is a necessary condition of the regional development. One of the most important functions of the regional authorities is the strategy of the sustainable development of the region as the basis of maximization of regional competitiveness of business and improvement of the population quality of life.

The fundamentals of the theory of sustainable development were formulated in the early 1990s, the idea of a dynamic and balanced development of the economy, nature and society is justified in a number of UN documents, and international agreements have been concluded.

The aim of the study is to develop the methodological instruments for choosing a strategy for ensuring the sustainable development of a region in a decentralized environment. The hypothesis of the study: the choice of a regional development strategy requires consideration of its financial sustainability and the risk of reducing the sustainable development, which should be provided with appropriate methodological instruments.

The structure of this study reflects the formed research-and-scientific goal. The first section of this article examines the essence of strategic planning at the regional level. The second section is devoted to technology of the selection strategies for the sustainable development of the region in the context of decentralization. The results are discussed in the third section. At the end of this paper we discuss objections, replies, and clarifications.

\section{LITERATURE REVIEW}

For effective implementation of strategic planning, it is necessary to know and understand its essence. The dynamic development of market processes in Ukraine significantly enhances the role of the scientific substantiation of the development of the region in the context of decentralization, and the use of the theory of strategic planning is important in this process. The strategic planning of the sustainable development of the region in modern conditions is considered as one of the most promising and effective mechanisms for the implementation of 
DOI: 10.14807/ijmp.v11i6.1156

long-term regional policies in the context of increasing their self-organization (ALEKSANDROV, 2010; FOMINA,2010; KORYTKO, 2011; SOLDAK, 2014).

Understanding the essence of the concept of "strategic planning" is constantly changing and acquiring a new meaning under the influence of factors of the region modern development (AMOSHA, 2006; SCHENDEL, 1972; HIGGINS, 1983; PEARSE, 1985; BILA, 2011; PYSHKAR, 2008). The modern view of the regional strategic management requires taking into account the peculiarities of adapting the methodological instruments to modern realities, as well as further research on issues related to the methodology of implementing the strategic management system.

Strategic planning occupies a central position in the system of strategic management, which ensures the interaction of two other elements - the development of a strategy and the implementation of this strategy.

The existence and development of the region in modern conditions necessitate the use of the basic provisions of the strategic planning and the formulation of a clear strategy for ensuring the sustainable development of the region (TISHCHENKO, 2010) Therefore, it is important to understand the essence of the concept of "strategy". In the economic literature there is a fairly large number of definitions of strategies that are different in their essence and those that reflect the philosophical, procedural, behavioral, effective, structural and other aspects of this category. Thus, the organizational and economic essence of the strategy for ensuring the sustainable development of the region should be considered in three dimensions of this concept.

In the framework of the first approach, the strategy of ensuring the sustainable development of the region is considered as a documented expression about the desired future state of the economy and social sphere of the region and about the system of measures and resources used by the authorities to approximate this future (ANSOFF, 1990; TISHCHENKO, 2010).

In the second approach, a strategy is defined as a strategic development plan, which is a specific long-term plan for achieving a specific goal, and the formation of a strategy is the process of finding a specific goal and drawing up a long-term plan. Such an approach is based on the fact that all changes in the environment are predictable, they are determined and can be controlled and managed (DOYLE, 2006; SHAROV, 2002; MINTZBERG, 1987; MESCON, 1981; THOMPSON, 2013; HERSHUN, 2005; TARASOVA, 2019). 
DOI: 10.14807/ijmp.v11i6.1156

In accordance with the third approach, the strategy is considered as a process that is a system of documents on strategic management in conjunction with organizational structures and procedures, setting specific, constantly reproducible strategies for developing strategies and ensuring the implementation of strategic goals and objectives (MATVIYENKO, 2005; KAKASHNIKOVA, 2008; PUKHYR, 2005; CHEREVKO, (2007).

Thus, the strategy of sustainable development of the region is a conceptual document of regional strategic planning, reflecting the main activities, goals, priorities and means of regional policy to ensure the sustainable development of the region in the long term prospect in conditions of a sluggish military conflict and reduced industrial potential and territory.

The modern development of the regional economy is influenced by the adverse challenges of the external environment. Crisis trends in the economy make it necessary to determine the quantitative characteristics of influence in the socio-economic environment (AHARKOV, 2009). In this situation, a prerequisite for regional development is the development and application of effective instruments of state regulation policy. One of the most important functions of regional authorities in emergency conditions is the formation of a strategy to ensure the sustainable development of the region as the basis for maximizing the regional competitive advantages of business and preserving the quality of life of the population.

\section{METODOLOGY}

The technology of choosing a strategy for ensuring the sustainable development of the region in emergency conditions is shown in Figure 1.

- Stage 1. Definition of a mission. The mission is a steady increase in the level and quality of life of the population, it is ensured by the development of economic potential and the social sphere, by increasing the involvement of the population in solving the problems of the region.

- Stage 2. The definition of strategic goals and the establishment of causal relationships between them should be carried out in the form of a strategic map.

- Stage 3. Outlining and classification of the factors that influence the sustainable development of the region in emergency conditions. This stage includes the analysis of the external and internal environment of the region functioning.

To analyze the factors of the external and internal environment of the region that affect its sustainable development, you should: 
- determine the composition of factors of the external and internal environment of the region;

- trace the stages of the decomposition of the strategy into the scorecard;

- identify those areas that most directly or indirectly affect sustainable development;

- select specific factors of the external and internal environment of the region that influence the formation of the strategy;

- analyze the influence of the selected factors.

The main factors of the external environment that influence the development of the region are: economic actors, authorities, and social and political processes outside the region.

The most important is to take into account specific mechanisms of interaction (change of which does not always lead to a change in strategy, but should be reflected in the action plan of regional authorities) with key environmental groups for the region, such as government, international corporations, etc. Taking into account the complexity of the region as a socioeconomic system, and the fact that internal factors will primarily affect the choice of strategy, internal factors include: resources (financial, material, labor), business, administration, infrastructure, and territory.

To analyze the factors of the external and internal environment, it is advisable to use an effective and at the same time quite simple SWOT analysis method. This method consists in the mutual comparison of the strengths and weaknesses of the internal environment and the possibilities and threats of the external environment of the region.

4 stage. Assessment of financial sustainability and the risk of losing sustainable development in the region. The financial sustainability of the region is one of the main indicators characterizing the budget capacity, the possibility of forming its own budget revenues and the total budget revenues of the region. One of the most important indicators characterizing the possibility of an economic crisis at the regional level is the low level of financial stability. By itself, this indicator cannot indicate a crisis, but its deterioration is a symptom for a more detailed diagnosis of the state at the regional level (BULEEV, 2010). 
ISSN: 2236-269X

DOI: 10.14807/ijmp.v11i6.1156

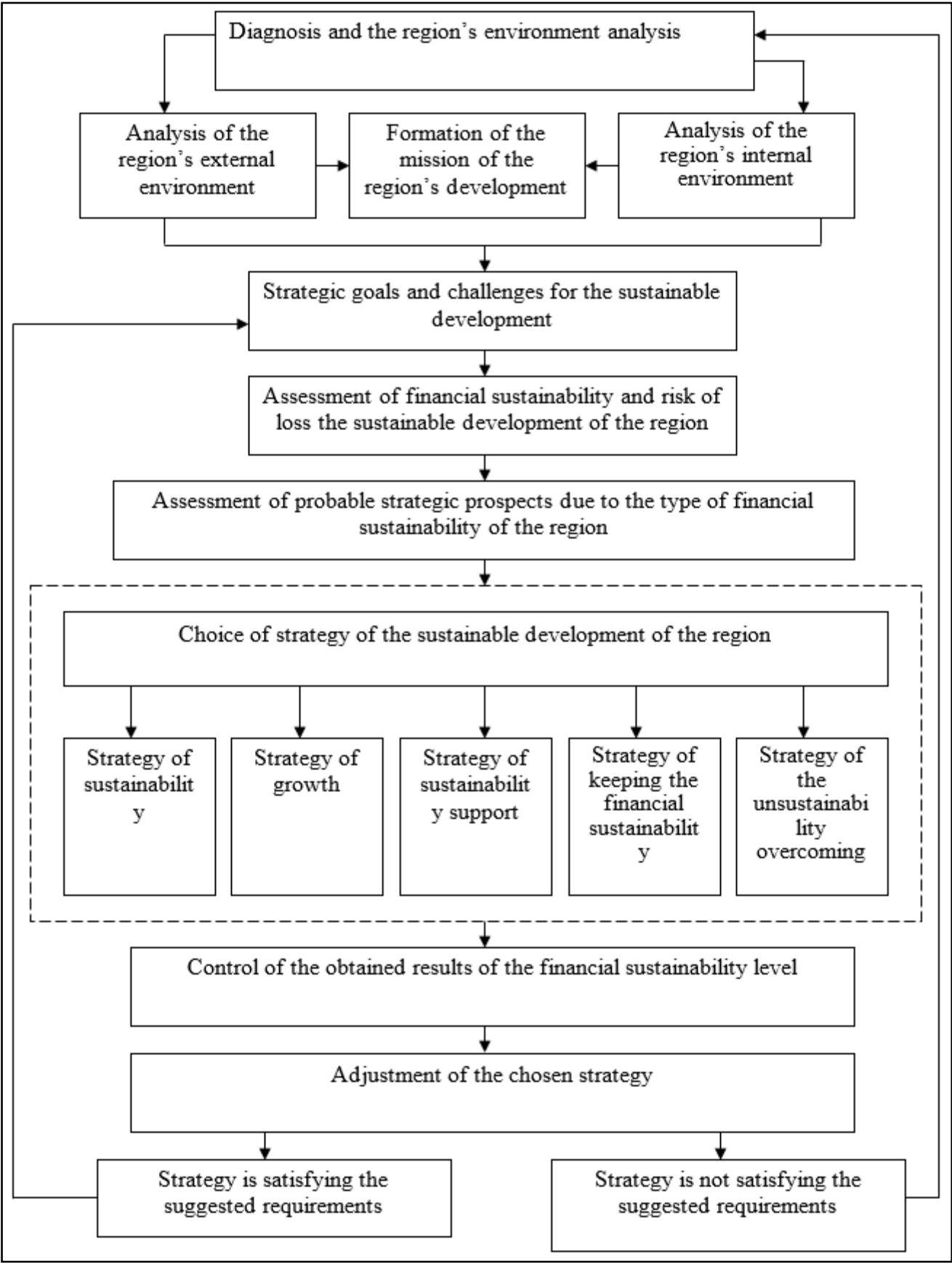

Figure 1: A generalized chart of technology of selection strategy for the sustainable development of the region in a decentralized environment

Source: own research

In order to make a qualitative assessment of financial sustainability of the region, it is necessary to analyze its level and consider it in dynamics, Table 1.

Table 1: Matrix of the level of financial sustainability of the region and its dynamics

\begin{tabular}{|l|l|}
\hline The level of financial sustainability & Type of financial sustainability \\
\hline $1-0,81$ & absolutely financially sustainable \\
\hline $0,61-0,80$ & financially sound \\
\hline $0,41-0,60$ & relatively stable \\
\hline $0,21-0,40$ & financially unstable \\
\hline $0-0,20$ & crisis \\
\hline
\end{tabular}


At this stage it is necessary to assess the likelihood of each element the risk of reducing the sustainable development of the region in scores according to Table 2.

Table 2: Graduation the risk of reducing the sustainable development of the region based on the likelihood of its occurrence

\begin{tabular}{|l|l|l|l|}
\hline $\begin{array}{l}\text { Pqi } \\
\text { (scores) }\end{array}$ & Risks & Probability of Ii, \% & Characteristic of event \\
\hline 1 & Weakly probable & $0<\mathrm{P} \leq 10$ & The exceptional event \\
\hline 2 & Not likely & $10<\mathrm{P} \leq 40$ & The event will unlikely happen \\
\hline 3 & Probable & $40<\mathrm{P} \leq 60$ & $\begin{array}{l}\text { The event will take place with a sufficient } \\
\text { degree of probability }\end{array}$ \\
\hline 4 & Highly probable & $60<\mathrm{P} \leq 80$ & $\begin{array}{l}\text { The event will take place with high } \\
\text { probability }\end{array}$ \\
\hline 5 & Expected & $90<\mathrm{P} \leq 100$ & The event must be held \\
\hline
\end{tabular}

Probability interval ranges from 0 to $100 \%$. The risk with a probability of $100 \%$ is fully expected. Determining the likelihood of losing the risk of reducing the sustainable development of the region made based on peer review.

The next step is similarly assessing the magnitude of potential losses in values according to Table 3 .

Table 3: Grading the risk of reducing the sustainable development of the region in terms of losses

\begin{tabular}{|l|l|l|}
\hline Pqi (points) & Losses & The magnitude of losses (Ii), \% \\
\hline 1 & Minimal & $0<\mathrm{I}<=20$ \\
\hline 2 & Low & $20<\mathrm{I}<=40$ \\
\hline 3 & Middle & $40<\mathrm{I}<=60$ \\
\hline 4 & High & $60<\mathrm{I}<=80$ \\
\hline 5 & Maximum & $>80$ \\
\hline
\end{tabular}

Further, the index calculates the risk of reducing the sustainable development of the region, which is the significance of scoring risk as follows:

Iri $=$ Pqi $\times I q i$

where Iri - index risk, in points;

$\mathrm{Rq}_{\mathrm{i}}$ - the likelihood of risk in points;

$\mathrm{Iq} q_{\mathrm{i}}$ - the likely magnitude of losses in points.

The next step is to assess the degree of action identified risks, as a result of which the experts can identify the risk of reducing the sustainable development of the region.

Thus, if the risk of reducing the sustainable development of the region index exceeds the acceptable level, it is necessary to identify key risk factors and develop their complex 
DOI: 10.14807/ijmp.v11i6.1156

relation of activities to optimize its value. However, if the risk of reducing the sustainable development of the region index within eligibility, this does not mean that the risk does not need to be managed. In this case, risk management is in working order with constant revaluation of its level.

Graduation the risk of reducing the sustainable development of the region depending on the degree of influence given in Table 4.

Table 4: Grading the risk of reducing the sustainable development of the region, depending on the degree of impact

\begin{tabular}{|l|l|l|}
\hline Influence degree & Risk index (Iri) & Characteristics \\
\hline Minimal & $10<\mathrm{Ir}<=20$ & $\begin{array}{l}\text { The impact of risk on the financial sustainability of the territorial } \\
\text { community is missing }\end{array}$ \\
\hline Low & $20<\mathrm{Ir}<=40$ & $\begin{array}{l}\text { Low risk of losing financial sustainability of local community. Easily } \\
\text { removed, so are allowable ones. }\end{array}$ \\
\hline Middle & $40<\mathrm{Ir}<=60$ & $\begin{array}{l}\text { Leading to increased financial losses. Required interventions to } \\
\text { decreasing }\end{array}$ \\
\hline High & $60<\mathrm{Ir}<=80$ & $\begin{array}{l}\text { High risk of losing financial sustainability. Required preventive } \\
\text { measures }\end{array}$ \\
\hline Maximum & $80<\mathrm{Ir}<=100$ & $\begin{array}{l}\text { Invalid degree of influence. There is a high probability of loss of } \\
\text { financial sustainability }\end{array}$ \\
\hline
\end{tabular}

Stage 5. Assessment of possible strategic prospects. Criteria for assessing the degree of achievement of the values of the planned indicators allow us to judge the degree of achievement of the implementation of the strategy for ensuring the sustainable development of the region in emergency conditions. The magnitude of the discrepancy between the planned and actual results of the implementation of the strategy for ensuring the sustainable development of the region in emergency conditions makes it possible to determine not only the direction of its adjustment, but also the growth in the need for resources.

Stage 6. The choice of strategies to ensure the sustainable development of the region in emergency conditions. This choice is based on making a matrix of strategies. One of the indicators for choosing a strategy for ensuring the sustainable development of the region in emergency conditions is the type of financial sustainability determined on the basis of an integral indicator of financial sustainability: absolutely financially sustainable, financially sustainable; relatively sustainable; financially unsustainable, crisis. The second component of the matrix for choosing a strategy for ensuring the sustainable development of the region in emergency conditions is an index of the risk of losing the sustainable development of the region.

The matrix for choosing a strategy for the region's sustainable development in emergency conditions is shown in Figure 2. 
Quadrants 2, 3, 4, 5 (figure 2) correspond to the strategy of sustainability, which is a focus on existing activities and their support. This strategy is formed in an environment where the strategies of growth are unacceptable as a result of the increasing influence of risk on the sustainable development of the region.

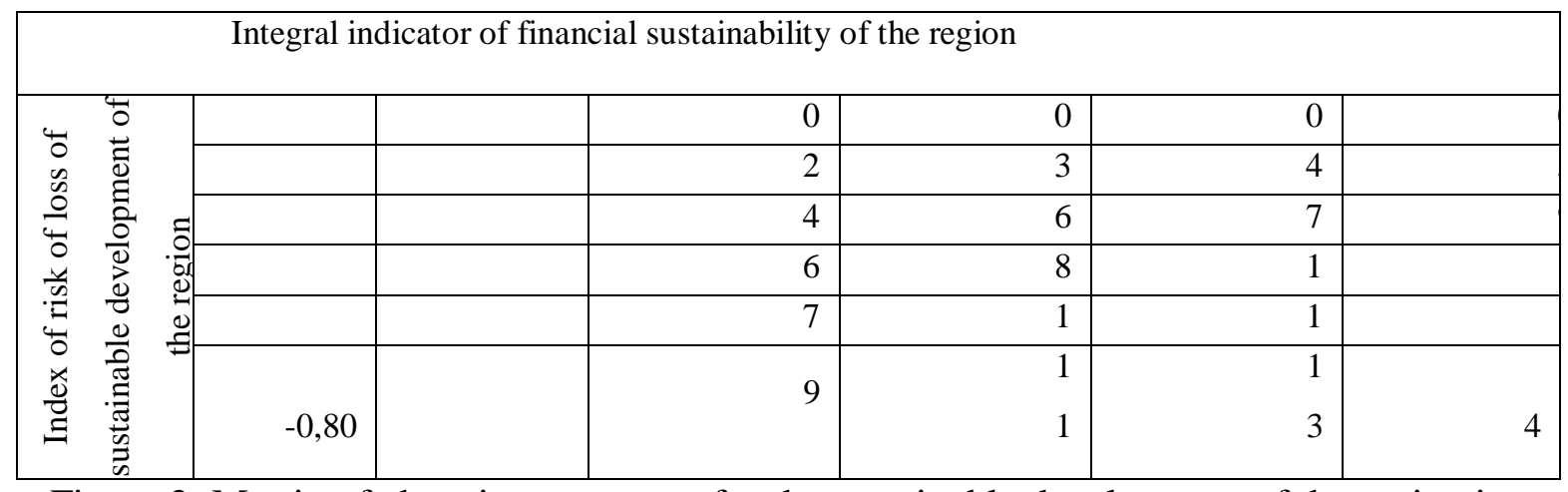

Figure 2: Matrix of choosing a strategy for the sustainable development of the region in emergency conditions

Source: own research

When implementing this strategy, a moderate influence of risk factors on the sustainable development of the region is observed. It is necessary to develop and implement measures to overcome the crisis. Ensuring the stability of development will allow the region to leave the danger zone of the matrix. Not all development opportunities are feasible. Stable and dynamic activities will provide an opportunity to a further improvement of the financial sustainability of the region.

Quadrant 1 (figure 2) corresponds to the strategy of growth, which is characterized by a dynamic level of development of the potential for the sustainable development of the region.

When implementing this strategy, there is a type of absolute financial stability of the region with a minimum degree of risk. Regional authorities are satisfied with the current growth rates of the activities of economic entities that operate at the regional level, the debt volumes have not changed, although there are economic prerequisites for this. The existing financial potential can provide an increase in the level of financial stability of the region.

Quadrants 6, 7, 8, 9 (figure 2) are characterized by a strategy of the sustainability support, which is a process of ensuring the financial sustainability, taking into account the region's gradual transition to a higher level of development and aimed at organizing the efficient operation of all elements on which the final result of activities depends.

When implementing this strategy, an adverse effect of risk factors on the level of the financial sustainability of the region is observed. Regional government authorities seek to 
DOI: 10.14807/ijmp.v11i6.1156

maintain financial sustainability only by increasing debt. To finance the development of the region own sources are not enough due to the low efficiency of management. Financial equilibrium is unsustainable, a crisis is brewing.

Quadrants 10,11, 12 figure 2 are characterized by a strategy of containing financial sustainability, which provides for the achievement and support of financial stability in the conditions of negative influence of risk factors.

When implementing this strategy, there is a high level of influence of risk factors on the level of financial sustainability of the region. One of them is an unsustainable state of the region's economy. Consequently, the region balances between the danger of moving to the lowest square of the matrix (if negative trends in changing financial sustainability prevail) and the prospect of moving to higher squares (while ensuring positive development trends).

Quadrants 2, 3, 4, 5 (figure 2) correspond to the strategy of overcoming the instability, which is characterized by an increase in the negative impact of the crisis and the unsustainability of the development of the region, as well as a steady downward trend in the level of financial stability is observed.

When implementing this strategy, there is a significant impact of risk factors on the level of financial sustainability of the region. The region is in crisis. To improve the situation, a complex system of financial and economic recovery is necessary. It is necessary to achieve increasing the results of financial and economic activities of economic entities at the regional level. It is advisable in the future to bring the region closer to potential development limits.

Classification of types of strategy for the sustainable development of the region in emergency conditions allows you to search for such a variant of the strategy, which gives the optimal ratio between the existing capabilities and the desired results of the functioning of the region. The choice of one or another variant of the strategy for ensuring the sustainable development of the region in emergency conditions requires the distribution of the analyzed regions by areas of quantitative assessment of their financial sustainability, taking into account the risk factor, which allows regional authorities to choose the optimal strategy.

Stage 7. Assessment of the effectiveness of the implementation of the strategy for ensuring the sustainable development of the region in emergency conditions. The formation and implementation of the strategy to ensure the sustainable development of the region in emergency conditions is one of the most important steps in strategic planning. The effectiveness of strategic planning is measured by the size of the contribution it makes to the 
DOI: 10.14807/ijmp.v11i6.1156

achievement of the goals and the implementation of the tasks set, minus the costs and undesirable consequences that arise in the formation of the strategic plan and its implementation. In order to assess the realism of the tasks and determine ways to achieve the goals, it is necessary to assess the effectiveness of the implementation of the planned activities.

Stage 8. Adjustment strategy. At this stage, the indicators achieved by the region are closer to the target, the adoption of relevant management decisions and measures for their practical implementation. The ineffectiveness of the implementation of the strategy for ensuring the sustainable development of the region in emergency conditions necessitates its adjustment.

The adjustment is carried out in the following areas:

- strategies in general;

- individual programs adopted as part of the implementation of the strategy;

- plans for the implementation of the strategy.

Thus, the use of the suggested methodological instruments creates a basis for assessing the effectiveness of the implementation of the strategy for ensuring the sustainable development of the region in emergency conditions, and allows you to quickly compare and identify existing positive and negative trends in the implementation of strategic initiatives.

\section{RESULTS}

The implementation of ensuring the financial sustainability of the region is not possible without conducting comprehensive monitoring and analysis, allowing assess the effectiveness of the established system for managing of the sustainable development.

At the first stage, respectively, with the suggested technology for choosing a strategy for ensuring the sustainable development of the region in emergency conditions, we will calculate its level of financial sustainability using the example of the Donetsk region.

To carry out the level of financial sustainability, it is necessary to form an information array, on the basis of which the formation of a system of groups of indicators takes place, in the context of the components of a study of the financial sustainability of a region: financial, demographic, economic, personnel.

By means of multiple regression modeling, the integral indicator of financial stability of the n-th region in the $\mathrm{t}$-th period is calculated. 
ISSN: 2236-269X

DOI: 10.14807/ijmp.v11i6.1156

$I_{\phi y}=a_{1} X_{1}+a_{2} X_{2}+a_{3} X_{3}+\ldots+a_{n} X_{n}$,

(2)

where $\mathrm{x}_{1,2,3, \ldots \mathrm{n}}$ - indicators that characterize the components of the financial sustainability of the region;

$\mathrm{a}_{1}, \mathrm{a}_{2}, \mathrm{a}_{3}$ - regression coefficients;

$\mathrm{a}_{0}-$ is a free member.

The value of the integral indicator of financial stability of the Donetsk region is shown in Table 5.

Table 5: The value of the integral indicator of financial stability of the Donetsk region

\begin{tabular}{|l|l|l|l|l|l|}
\hline \multirow{2}{*}{ period } & \multicolumn{5}{|l|}{ The value of the integral indicator } \\
\cline { 2 - 6 } & $\begin{array}{l}\text { Financial } \\
\text { component }\end{array}$ & $\begin{array}{l}\text { Demographic } \\
\text { component }\end{array}$ & $\begin{array}{l}\text { Economic } \\
\text { component }\end{array}$ & $\begin{array}{l}\text { Personnel } \\
\text { component }\end{array}$ & $\begin{array}{l}\text { Financial } \\
\text { sustainability }\end{array}$ \\
\hline 2014 & 0,791 & 0,751 & 0,693 & 0,596 & 0,720 \\
\hline 2015 & 0,761 & 0,695 & 0,702 & 0,785 & 0,680 \\
\hline 2016 & 0,727 & 0,659 & 0,616 & 0,648 & 0,600 \\
\hline
\end{tabular}

Source: own research.

On the basis of the obtained calculation results, the Donetsk region refers to the type of financial sustainability, which is characterized as being satisfactory, with negative dynamics of development. As the results of the calculation showed, the level of financial sustainability of the region decreased to 0.60 , which indicates a worsening of the situation that has developed.

One of the urgent problems in the field of risk analysis of socio-economic systems is the quantitative risk assessment. Realization of risks for the territory may violate the material basis of both the region itself and the well-being of the individual (KUKLIN, 2017).

At the second stage, we will calculate the risk of reducing the sustainable development on the example of the Donetsk region based on the methodical approach suggested in (KORYTKO, 2016). The results of the formation of the matrix ranking the risk of reducing the sustainable development on the example of the Donetsk region are shown in Table 6.

Table 6: Matrix of risk ranking for reducing sustainable development on the example of the Donetsk region

\begin{tabular}{|c|c|c|c|c|c|}
\hline \multirow{2}{*}{ Name of risk } & \multicolumn{2}{|c|}{ Probability Pqi } & \multicolumn{2}{|c|}{$\begin{array}{l}\text { The magnitude } \\
\text { of losses Ii }\end{array}$} & \multirow{2}{*}{$\begin{array}{l}\text { Risk } \\
\text { estimati } \\
\text { on }\end{array}$} \\
\hline & $\%$ & points & $\%$ & points & \\
\hline \multicolumn{6}{|l|}{ 1. Credit risk } \\
\hline $\begin{array}{l}1.1 \text { The risk of insolvency of economic entities that are located } \\
\text { in the region }\end{array}$ & 60 & 3 & 60 & 3 & 9 \\
\hline 1.2 Credit policy risk & 55 & 3 & 50 & 3 & 9 \\
\hline 1.3 Risk of financial loss & 60 & 3 & 50 & 3 & 9 \\
\hline \multicolumn{6}{|l|}{ 2. Political risk } \\
\hline 2.1 Legislative change risk & 40 & 3 & 50 & 3 & 9 \\
\hline
\end{tabular}


ISSN: 2236-269X

DOI: 10.14807/ijmp.v11i6.1156

\begin{tabular}{|l|l|l|l|l|l|}
\hline 2.2 Risk of legislative change & 40 & 3 & 55 & 4 & 9 \\
\hline 2.3 The level of corruption of state structures & 60 & 3 & 45 & 3 & 9 \\
\hline 2.4 The risk of reducing the authority of regional authorities & 40 & 3 & 45 & 3 & 9 \\
\hline 3. General economic risk & & & & & \\
\hline 3.1 Stability of tax legislation & 30 & 2 & 25 & 2 & 4 \\
\hline 3.2 Inflation risk & 35 & 2 & 40 & 3 & 6 \\
\hline $\begin{array}{l}\text { 3.3 The risk of reducing the development of the regional } \\
\text { economy }\end{array}$ & 60 & 3 & 35 & 3 & 9 \\
\hline $\begin{array}{l}\text { 3.4 The risk of reducing the official rate of the national } \\
\text { currency to foreign currencies }\end{array}$ & 50 & 3 & 35 & 3 & 9 \\
\hline 4. Socio-demographic risk & & & & & \\
\hline 4.1 Population risk & 70 & 4 & 60 & 3 & 12 \\
\hline 4.2 Health Risk Reduction & 50 & 3 & 25 & 2 & 6 \\
\hline 4.3 Risk of declining living standards & 40 & 3 & 40 & 3 & 9 \\
\hline 4.4 Unemployment Risk & 35 & 2 & 55 & 4 & 8 \\
\hline 4.5 Risk of declining education & 25 & 2 & 25 & 2 & 4 \\
\hline 5. Natural and environmental risk & & & & & \\
\hline 5.1 Risk of sustainable technological actions & 60 & 3 & 55 & 4 & 12 \\
\hline 5.2 Risk of contamination of the natural environment & 75 & 4 & 55 & 4 & 16 \\
\hline 5.3 Risk of reducing naturally agrarian potential & 20 & 1 & 15 & 2 & 2 \\
\hline 6. Investment risk & & & & & \\
\hline 6.1 Risk of sensitivity to the environment & 70 & 4 & 35 & 2 & 8 \\
\hline 6.2 Risk of lower capital investment & 60 & 2 & 50 & 4 & 12 \\
\hline 6.3 The risk of reducing businesses that innovate & 55 & 2 & 50 & 4 & 12 \\
\hline
\end{tabular}

Source: own research

On the basis of the data obtained as a result of the survey of experts and systematized in Table 6, we make a risk map (Figure 3).

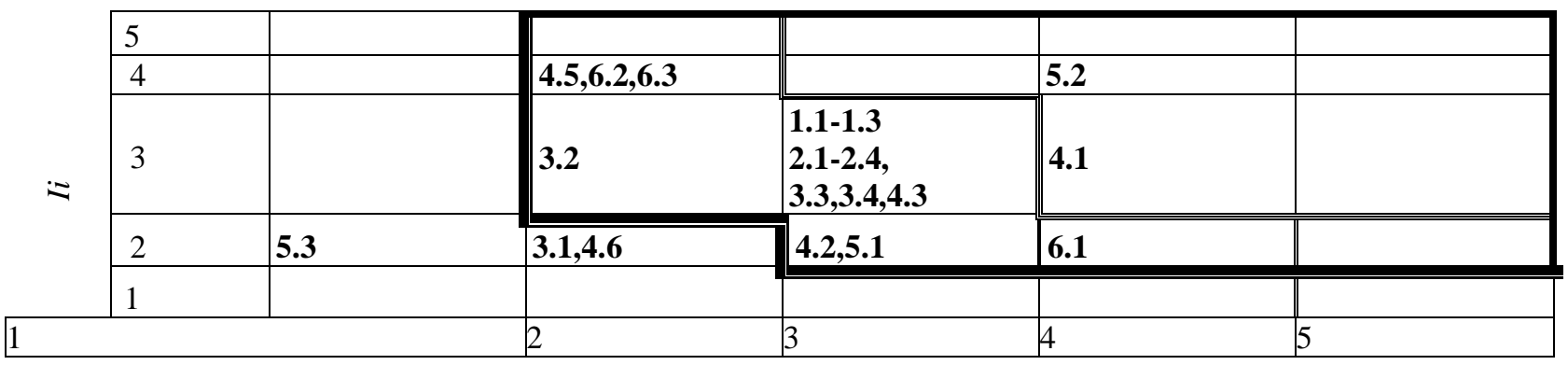

Pqi Figure 3: Risk map for reducing the sustainable development of the Donetsk region Source: own research

A qualitative assessment of the risk of reducing sustainable development on the example of the Donetsk region suggests that most of them are in the area of significant and high level. The risks that are below the tolerance line need constant management.

On the basis of the data obtained and using the matrix of choice of a strategy for ensuring the sustainable development of the region in emergency conditions, which is shown in Fig. 2 we define the appropriate strategy. Consequently, the Donetsk region falls into quadrant 6, that is, a strategy to support the sustainability, which is the process of ensuring financial sustainability, taking into account the region's gradual transition to a higher level of 
DOI: 10.14807/ijmp.v11i6.1156

development and aimed at organizing the efficient operation of all the elements on which the final result of activities depends.

\section{CONCLUSIONS}

Based on a review of domestic and foreign literature, the author's definition of the concept of a strategy of the sustainable development of the region in emergency conditions is given as a conceptual document of regional strategic planning reflecting the main activities, goals, priorities and means of regional policy to ensure the sustainable development of a region in a long-term military conflict and reduced industrial potential and territory.

The authors suggested methodological instruments that allow you to make a choice of a strategy for the sustainable development of the region in emergency conditions, which, unlike the existing ones, is to take into account the influence of a risk factor and the level of financial sustainability of the region in emergency situations.

Testing of the developed methodological instruments was carried out on the basis of indicators of the part of the Donetsk region controlled by the Ukrainian authorities. In the conditions of military-political instability, it is characteristic the adverse effect of risk factors on the level of financial stability of a region.

The developed methodological instruments form the basis for decision-making by the authorities on the choice of strategy and assessment of the effectiveness of its implementation in emergency conditions, which makes it possible to quickly compare and identify existing positive and negative trends in the implementation of strategic initiatives, as well as develop an effective risk management system at the regional level in collaboration with government authorities.

\section{REFERENCES}

AHARKOV, H. A.; NAYDENOV, A. S.; CHUSOVA, A. E. (2009) Vlijanie social'noerjnjmicheskikh posledstvijj mirovogo tronomicheskogo krizisa yf tenevojj sector ekonomiki regiona. Regional economy, n. 4, p. 207-211.

ALEKSANDROV, I. O.; POLOVYAN, O. V. (2010) Stratehiya staloho rozvydku rehiobu. Donetsk: Noulidzh Publ, 203.

AMOSHA, O. I.; VISHNEVSKIY, V. P.; ZEMLYANKIN, A. I. (2006) Rehulyuvannya rehionalnoyi rozvytku v Ukrayini. Ekonomika Ukrayiny, n. 1, p. 45-59.

ANSOFF, H. I. (1990) Implanting Strategic Management. New York : Prentice-Hall, 520.

BILA, S. O. (2011) Stratehiya rozvytku rejioniv: shyakhy zabepechennya diyevosti. Kiyiv: NIDS Publ, 88. 
BULEEV, I. P.; KORYTKO, T. YU. (2010) Peredymovu vuneknennia ta formu protikannia kruzovukh protsesiv biudzhetiv mistsevoho rivnia. Visnuk DonYEP. n. 1, p. 29-35.

CHEREVKO, O. V. (2007) Stratehiya sotsialno-ekonomichnoho rozvytku rehioniv Ukrayini: avtoref. dis. doktora ekonomicheskikh nauk: 08.00.05. Kyiv, 40.

DOYLE, P. (2006) Marketing Management and Strategy. Pearson Education Limited, 464.

FOMINA, M. V. (2010) Problemy staloho ekonomichnoho rozvytlu v umovakh hlobolizatsiyi. Donetsk: DonNUET Publ, 359.

HERSHUN, A.; HORSKIU, M. (2005) Tekhnolohii sbalansirovannoho upravleniya. Moscow: ZAO «Olimp-biznes» Publ,. 416

HIGGINS, J. M. (1983) Organizational Policy and Strategic Management. Text and Cases. Chicago : The Dryden Press, 237.

KAKASHNIKOVA, T. M. (2008) Naukovo-metodychne formuvannya stratehiyi rozvytku rehionny: dis. kandidat ekonomicheskikh nauk: 08.00.05. Donetsk, 178

KORYTKO, T. YU. (2011) Teoretychni aspecty stratehichnoho planuvannia regionalnoho rozvutku. Visnuk DHMA, v. 3, n. 24, p. 127-132.

KORYTKO, T. YU. (2016) Estimation of risk of loss of financial firmness by territorial society. Ekonomichnuy visnuk Natsionalnoho hirnuchoho universutety, v. 1, n. 53, p. 6775.

KUKLIN, A. A.; PECHERNINA, M. S.; TYRSIN, A. N. (2017) Metodicheskijj instrymenrarijj diagnostiki riskov dlha blagosostojanija lichnosti I territorii prozhyvanija. Regional economy, n. 13, p. 1030-1043. htt://dx.doi 10.17059/2017-4-5

MATVIYENKO, P. O. (2005) Upravlinnya rehionalnym rozvytkom v umovakh perekhidnoyi ekonomiky: dis. ... kandidat ekonomicheskikh nauk: 08.01.01. Kyiv, 223.

MESCON, M.-H. (1981) Management: individual and organization Cambrige : Harper and row, 464.

MINTZBERG, H. (1987) The Strategy Concept I: Five Ps For Strategy. California Management Review. n. 1, p. 11-24.

PEARSE, J. A.; ROBINSON, R. B. (1985) Strategic Management. Richard D. Irwin, 268. PUKHYR, S. T. (2005) Stratehichne prohnozuvannya sotsialno-ekonomichnoho rozvytku rehionny dis. kandidat ekonomicheskikh nauk: 08.01.01. Lviv, 186

PYSHKAR, Z.; PYSHKAR, B. (2008) Stratehichne planyvannia rehionalnoho rozvutky. Nayka moloda: munyle, sychasne, maybutnie, n. 13, p. 100-105.

SCHENDEL, D. E.; HATTER, K. J. (1972). Business Policy or Strategic Management: A Broader View for an Emerging discipline, Academy of Management Proceeding, p. 4

SHAROV, YU. P. (2002) Mtnjdjkjuschni zasady strstehichnoho planuvannya v munitsipalnomu menedzhmenti: dis. ... doktora derzh. uprav. nauk: 25.00.04. Kyyiv, 390.

SOLDAK, M. O. (2014) Priorutetni napriamu stratehichnoho planuvannia rozvutku promuslovoho mista . Economichnui visnuk Donbasu. n. 3(37), p. 25-29.

TARASOVA, H.; ZAHAROV, S.; VERESKUN, M.; KOLOSOK, V. (2019) Preventive anticrisis strategy for development of industrial enterprise independent. Journal of 
ISSN: 2236-269X

DOI: 10.14807/ijmp.v11i6.1156

management \& production, v. 10, n. 5, September-October, p. 1405-1420. htt://dx.doi: 10.14807/ijmp.v10i5.890

THOMPSON, A. A.; STRICKLAND, A. J.; GRAMBLE, J. E. (2013) Crafting and Executing Strategy. New York : McGraw-Hill/Irwin, 592 p.

TISHCHENKO, A. P. (2010) Stratehichnie planuvannia roxvutku rehionu: osnovni poniattia, vumohu I alhorutm zdiysnennia Economichnui visnuk Donbasu, v. 2, n. 10, p. 84-89. 